IZA DP No. 724

The Impact of Deunionisation on Earnings Dispersion Revisited

John T. Addison

Ralph Bailey

W. Stanley Siebert

February 2003 


\title{
The Impact of Deunionisation on Earnings Dispersion Revisited
}

\author{
John T. Addison \\ University of South Carolina and IZA Bonn \\ Ralph Bailey \\ University of Birmingham \\ W. Stanley Siebert \\ University of Birmingham
}

\author{
Discussion Paper No. 724 \\ February 2003
}

\author{
IZA \\ P.O. Box 7240 \\ D-53072 Bonn \\ Germany \\ Tel.: +49-228-3894-0 \\ Fax: +49-228-3894-210 \\ Email: iza@iza.org
}

This Discussion Paper is issued within the framework of IZA's research area Internationalization of Labor Markets. Any opinions expressed here are those of the author(s) and not those of the institute. Research disseminated by IZA may include views on policy, but the institute itself takes no institutional policy positions.

The Institute for the Study of Labor (IZA) in Bonn is a local and virtual international research center and a place of communication between science, politics and business. IZA is an independent, nonprofit limited liability company (Gesellschaft mit beschränkter Haftung) supported by the Deutsche Post AG. The center is associated with the University of Bonn and offers a stimulating research environment through its research networks, research support, and visitors and doctoral programs. IZA engages in (i) original and internationally competitive research in all fields of labor economics, (ii) development of policy concepts, and (iii) dissemination of research results and concepts to the interested public. The current research program deals with (1) mobility and flexibility of labor, (2) internationalization of labor markets, (3) welfare state and labor market, (4) labor markets in transition countries, (5) the future of labor, (6) evaluation of labor market policies and projects and (7) general labor economics.

IZA Discussion Papers often represent preliminary work and are circulated to encourage discussion. Citation of such a paper should account for its provisional character. A revised version may be available on the IZA website (www.iza.org) or directly from the author. 
IZA Discussion Paper No. 724

February 2003

\section{ABSTRACT \\ The Impact of Deunionisation on Earnings Dispersion Revisited}

This paper examines the effects of union decline in Britain on changes in earnings dispersion between 1983 and 1995. As part and parcel of the exercise, the effects of changes in the wage gap and the variance gap are also calculated. Detailed findings are provided by gender and broad sector, allowing for worker characteristics and the skill gradient. Deunionisation is shown to account for surprisingly little of the increase in earnings dispersion in the private sector for either males or females. Although union decline has been more muted in the public sector, union effects are actually stronger here. In the public sector, unions no longer reduce earnings variation as much they once did by virtue of their growing tendency to organise more skilled groups.

JEL Classification: D3, J31, J51

Keywords: deunionization, union structure, earnings dispersion, wage gap, variance gap, private/public sector

Corresponding author:

John T. Addison

Department of Economics

Moore School of Business

University of South Carolina

Columbia, SC 29208

USA

Tel.: +1 8037774608

Fax: +1 8037776876

Email: ecceaddi@moore.sc.edu 


\section{Introduction}

The British earnings distribution has widened considerably since Mrs Thatcher's sustained attack on the unions. The possibility of there being a connection between the two developments has been the subject of a fairly large literature. In this paper, we revisit the subject, using the general variance decomposition technique first put forward by Freeman (1980) and Metcalf (1982). We follow Card's (2001) modification of this approach to allow for changes in the "structure" of unionisation across the workforce; specifically, the greater decline in union density among the lower paid than the higher paid. Using this method, and allowing for changes in union wage and variance gaps, as well as union density, we show that the effect of deunionisation on earnings dispersion has on the whole been more modest than generally believed.

Certainly, casual inspection shows a striking association between movements in union density over time and changes in the earnings dispersion (see Leslie and $\mathrm{Pu}, 1996$, Figure 4d). Emphasising this link, Schmitt (1995, p. 201) has calculated that the decline in union density could account for 21 per cent of the rise in the pay premium for a university degree and for 13 per cent of the increase in the non-manual differential, 197888. Machin (1997, p. 653) obtains more dramatic results: comparing 1983 with 1991, he calculates that the male earnings variance would have been 40 per cent less had the 1983 levels of union coverage prevailed in 1991. Bell and Pitt (1998, pp. 520, 523) also conclude that deunionisation between the early 1980s and 1990s widened the male earnings distribution - in this case by about 20 per cent.

That said, not all research points the same way. Notably, in their recent analysis of the wage distribution of U.K. males, Gosling, Machin, and Meghir (2000, p. 661) do not even mention unions. Instead, they emphasise education: the way recent cohorts have improved their acquisition of education, as well as changes over time in the returns to education. Moreover, Card (2001) has pointed out that the equalising effects of unionism can be exaggerated if we do not allow for the fact that unionisation effects vary across the wage distribution. He shows that if the structure of unionisation changes, so that union density falls less over time for the higher paid - as has happened both in the U.S. and the U.K. (see below) - then estimates of the equalising tendency of unionisation can be reduced. 
The plan of the paper is as follows. In the next two sections we first describe the datasets used before reviewing the variance decomposition approach (and deriving some descriptive results on changes in unionisation over time). In the fourth section we give the results of the variance decomposition analysis. Then, in the fifth section, given the diverging trends of unionisation in the public and private sectors, we present some results for the two sectors separately. The final section provides a summary and conclusion.

\section{The Data ${ }^{1}$}

We require data on earnings, unionisation, and individual characteristics over the last two decades. The earliest dataset available is the 1983 General Household Survey (OPCS, 1986) dataset (see also Machin, 1997; Gosling, and Lemieux, 2001). Furthermore, 1983 is the only year in which the General Household Survey included a union membership question, but this year is early enough to represent the "golden age" of unionism. For the later period, we choose the 1995 Labour Force Survey (OPCS, 2000), 1995 representing the nadir of the union movement's fortunes - and well before Labour's 1997 election victory. Most of the changes in unionisation and earnings dispersion had occurred by 1995 (see Card, Lemieux, and Riddell, 2003), and we therefore concentrate on this period.

The two datasets are comparable. In particular, union status is measured by the same question in both surveys: 'Are you a member of a trade union or staff association'? However, as regards union coverage, which would arguably better address the issue of union impact on wages, the survey questions differ. In the General Household Survey the question is: 'Is there a trade union or staff association where you work, which people in your type of job can join if they want to?' In the Labour Force Survey the question is simply: 'At your place of work, are there unions, staff associations, or groups of unions?' Hence, as with most of the literature, we restrict the analysis to union membership alone.

As regards the wage variable, we take several steps to ensure comparability. For both datasets, we restrict the sample to individuals aged 16-66 years, and not self-

\footnotetext{
${ }^{1}$ The original data creators, depositors or copyright holders, and the U.K. Data Archive bear no responsibility for our analysis and interpretation of the General Household Survey and the Labour Force Survey.
} 
employed. For both, we use the same hourly wage variable computed by dividing weekly earnings by usual hours. In addition, we convert the 1983 wage data to 1995 values using the retail price index. Finally, for both years we trim off observations with implausibly low or high wage rates, excluding hourly wages outside the $£ 1$ to $£ 45$ range. ${ }^{2}$

\section{Accounting for the Impact of Deunionisation}

There are different ways to account for the impact of deunionisation on earnings dispersion. First, various counterfactuals are possible. Most researchers have followed Freeman (1980) in computing the impact of deunionisation by asking what earnings dispersion would be if union density had not declined. However, there are two other important dimensions of unionism: the union wage gap, and the variance gap (the difference in the variance of wages for union and non-union workers). It is worth considering counterfactual changes in these dimensions as well. Second, as noted above, we can allow for differences in union density across skill groups. Let us look at these points in turn.

Beginning with the basic two-sector formulation, average wages $\bar{w}$ are

$$
\bar{w}=\mathrm{U} \bar{w}^{\mathrm{u}}+(1-\mathrm{U}) \bar{w}^{\mathrm{n}},
$$

where $\mathrm{U}$ is union density and the superscripts $\mathrm{u}$ and $\mathrm{n}$ refer to union and non-union respectively. This equation can be rewritten in terms of union "power", namely, union density multiplied by the union-nonunion wage gap

$$
\bar{w}-\bar{w}^{\mathrm{n}}=\mathrm{U} \Delta_{\mathrm{w}}
$$

where $\Delta_{\mathrm{w}}=\bar{w}^{\mathrm{u}}-\bar{w}^{\mathrm{n}}$ is the wage gap. This equation shows that the term $\mathrm{U} \Delta_{\mathrm{w}}$ determines the extent to which average wages are pushed above non-union wages, hence our term union power. It is important to consider how union power differs across the skill groups, which we do below.

The impact of unionism on the variance of average wages is what we wish to assess. Equation (1) provides a framework for estimating this effect. According to this equation, the variance of wages can be expressed in terms of union density, and the

2 These adjustments have a minor effect. Our 1995 figure for aggregate union density is $33.1 \%$, comparable with Brook's (2002, Table 1) figure of $32.3 \%$ for employees in Great Britain. 
union-non-union wage and variance gaps. Using Freeman's formula (1980, p. 19), the variance $(\mathrm{V})$ is

$$
\mathrm{V}=\mathrm{V}^{\mathrm{n}}+\mathrm{U} \Delta_{\mathrm{V}}+\mathrm{U}(1-\mathrm{U}) \Delta_{\mathrm{w}}{ }^{2},
$$

where $\Delta_{\mathrm{V}}=\mathrm{V}^{\mathrm{u}}-\mathrm{V}^{\mathrm{n}}$ is the union-non-union variance gap, $\mathrm{V}^{\mathrm{u}}$ and $\mathrm{V}^{\mathrm{n}}$ being the variance of wages in the union and non-union sectors, respectively. The impact of unionism is then $\mathrm{D}=\mathrm{V}-\mathrm{V}^{\mathrm{n}}$, namely, the overall wage variance minus the (larger) wage variance that would prevail without unionism. As can be seen, the impact can be decomposed into a term involving the union variance gap, $\mathrm{U} \Delta_{\mathrm{V}}$, the so-called 'within sector' effect, which is generally negative since $\Delta_{\mathrm{V}}$ is generally negative. The impact will also depend on the term $\mathrm{U}(1-\mathrm{U}) \Delta_{\mathrm{w}}$, the 'between sector' effect, which is positive since unions widen wage dispersion due to the union wage gap. On net, the impact of unionism on the variance of average wages is generally negative, since the variance gap effect tends to outweigh the wage gap effect. ${ }^{3}$

In assessing the impact of unionism on changes in wage variance over time - our focus here - we need to hypothesise what would have happened if unionism had taken a different path, that is, develop a counterfactual. Various approaches are possible. First, let us write an equation for the change in impact between time periods 0 and 1

$$
\mathrm{D}_{1}-\mathrm{D}_{0}=\mathrm{V}_{1}-\mathrm{V}_{0}-\left(\mathrm{V}^{\mathrm{n}}{ }_{1}-\mathrm{V}^{\mathrm{n}}{ }_{0}\right)=\mathrm{U}_{1} \Delta_{1 \mathrm{v}}-\mathrm{U}_{0} \Delta_{0 \mathrm{v}}+\mathrm{U}_{1}\left(1-\mathrm{U}_{1}\right) \Delta_{1 \mathrm{w}}{ }^{2}-\mathrm{U}_{0}\left(1-\mathrm{U}_{0}\right) \Delta_{0 \mathrm{w}}{ }^{2},
$$

where the subscripts indicate the time periods. Card (2001) compares $D_{1}$ with $D_{0}$. The counterfactual here is then the change in the non-union wage variance, $\mathrm{V}^{\mathrm{n}}{ }_{1}-\mathrm{V}^{\mathrm{n}}{ }_{0}$. For example, if deunionisation is causing a decline in union impact on the wage variance, the (negative) impact of unionisation will be smaller in period 1 than period 0 ; that is, in absolute terms, $\mathrm{D}_{1}<\mathrm{D}_{0}$. This condition requires the change in the overall wage variance to be greater than the change in the non-union wage variance, or $\mathrm{V}_{1}-\mathrm{V}_{0}>\mathrm{V}^{\mathrm{n}}{ }_{1}-\mathrm{V}^{\mathrm{n}}{ }_{0}$. Thus, changes in the non-union wage variance are meant to control for changes in the "other factors" which determine the overall wage variance. On this argument, the extent to which an increase, say, in overall wage variance is greater than an increase in the non-

\footnotetext{
${ }^{3}$ Equation (3) will not hold exactly if we adjust the wage or variance gaps for differences in characteristics of union and non-union workers, as we sometimes do (Table 1 shows such an adjusted wage gap). Equation (3) is basically useful because it provides a foundation for specifying the union within- and between-sector effects.
} 
union variance, measures the importance of reduced union power (i.e. lower density, and reduced wage and variance gaps).

But others (e.g. Freeman, 1991) compute a counterfactual union impact for period $1, \mathrm{D}^{\prime}{ }_{1}$, based on union density in period $0, \mathrm{U}_{0}$. The union variance and wage gaps are held constant at their period 1 levels. The measure here is

$$
\mathrm{D}_{1}-\mathrm{D}^{\prime}{ }_{1}=\left(\mathrm{U}_{1}-\mathrm{U}_{0}\right) \Delta_{1 \mathrm{v}}+\left(\mathrm{U}_{1}-\mathrm{U}_{0}\right)\left(1-\mathrm{U}_{1}-\mathrm{U}_{0}\right) \Delta_{1 \mathrm{w}}{ }^{2} .
$$

As can be seen, this measure weights the change in union density by period 1's variance gap, $\Delta_{1 \mathrm{v}}$, which is the main term given that the second term involves the near-zero factor, $1-\mathrm{U}_{1}-\mathrm{U}_{0}$. Thus, $\mathrm{D}_{1}-\mathrm{D}_{1}^{\prime}$ shows the extent to which the union impact in period 1 would be increased if period 0's union density alone prevailed. However, ignoring changes in wage and variance gaps over time seems arbitrary to us. Variance gaps - which are also a measure of union power - have in fact increased over time in Britain, as we will see. Therefore, while we will report $\mathrm{D}_{1}-\mathrm{D}_{1}{ }_{1}$ values for some analyses, for comparison, we will generally rely on the $\mathrm{D}_{1}-\mathrm{D}_{0}$ measure.

Let us now turn to the point that unionisation varies across skill groups. A way of showing this variation, following Card (2001), is to define skill groups using predicted earnings percentiles based on the non-union wage structure. We can then compare union densities across these skill groups. ${ }^{4}$ We can also consider how union "power" (viz. density multiplied by the wage gap, noted earlier) varies across skill groups. The picture for males (females) is given in Figures $1 \mathrm{a}$ and $1 \mathrm{~b}$ (Figures $2 \mathrm{a}$ and $2 \mathrm{~b}$ ).

(Figures $1 \mathrm{a}$ and $1 \mathrm{~b}$ near here)

Figure 1a shows that, for males in 1983, union density was lowest among the least skilled (lowest decile), highest at the third decile and then somewhat lower for the more skilled. Corresponding data for 1995 data show density falling most among the least skilled, leaving the highest density at the top decile. The male union density measure thus suggests that unions help a labour "elite". However, the picture is different for union

\footnotetext{
${ }^{4}$ The prediction equation is based on Card's (2001, p. 303) specification, and includes years of education, dummies for race, marital status and (5) regions, linear, quadratic and cubed experience, and interactions of five levels of education with linear and quadratic experience. It is fitted to non-union workers only, and then used to assign union and nonunion workers into ten equally-sized groups.
} 
power. Figure $1 \mathrm{~b}$ shows that union power was definitely greater in 1983 among the least skilled, although this had fallen by 1995 . Even in 1995, however, union power was least for the elite, an opposite pattern to that for union density. For females, the union density and union power graphs are more similar. Over time, both density and power have fallen among low skill groups, but have remained quite steady in the top three deciles. For women unionisation appears to have benefited an elite, and this pattern has become more pronounced over time. In particular, Figure $2 \mathrm{~b}$ shows that, particularly in 1995 , there is a positive covariance between union power and skill for women. ${ }^{5}$

(Figures $2 \mathrm{a}$ and $2 \mathrm{~b}$ near here)

Allowing for different union effects by skill category requires modification of equation (3). Card (2001, p. 298) shows that the formula becomes

$$
\mathrm{V}=\mathrm{V}^{\mathrm{n}}(\mathrm{c})+\overline{U \Delta_{V}}+\overline{U(1-U) \Delta_{w}^{2}}+\operatorname{Var}\left[\mathrm{U}(\mathrm{c}) \Delta_{\mathrm{w}}(\mathrm{c})\right]+2 \operatorname{Cov}\left[\mathrm{w}^{\mathrm{n}}(\mathrm{c}), \mathrm{U}(\mathrm{c}) \Delta_{\mathrm{w}}(\mathrm{c})\right] .
$$

$\mathrm{V}^{\mathrm{n}}(\mathrm{c})$ is the non-union wage variance, namely, the variance that would result if all workers were paid according to the non-union wage structure. ${ }^{6} \mathrm{U}(\mathrm{c})$ is union density in the c groups, $\Delta_{\mathrm{V}}(\mathrm{c})$ are the variance gaps, $\Delta_{\mathrm{w}}(\mathrm{c})$ are the wage gaps, and $\mathrm{w}^{\mathrm{n}}(\mathrm{c})$ are the non-union wage rates. The over-bar terms indicate averages over the c skill categories, and are analogous to the terms in equation (3). But the terms for variance and covariance between categories are new, and in practice we will find the covariance to be the most important. This covariance is precisely that between skill, $\mathrm{w}^{\mathrm{n}}$, and union power, $\mathrm{U} \Delta_{\mathrm{w}}$, which we have been discussing above in connection with Figures $1 \mathrm{~b}$ and $2 \mathrm{~b}$. A negative covariance term will indicate that unions are more helpful to the least skilled, and this

\footnotetext{
${ }^{5}$ It is likely that union power is overstated for low-skilled workers, and understated for the high skilled. Card (2001, p. 300) finds that low-skilled union workers have higher unobserved skills than their non-union counterparts, and the opposite for high-skilled union workers. Hence the true wage (in efficiency units) for the low-skilled union worker will be lower than the observed wage, leading to an overstatement of union power here, with precisely the opposite result for the high skilled. We do not make an adjustment for this factor, but it should be kept in mind when assessing the extent to which union power is "pro-poor".

${ }^{6} \mathrm{~V}^{\mathrm{n}}(\mathrm{c})$ will differ from $\mathrm{V}^{\mathrm{n}}$ in equation (3). $\mathrm{V}^{\mathrm{n}}(\mathrm{c})=\overline{V_{i}^{n}}+\operatorname{var}\left(\overline{X_{i}^{n}}\right)$, where $\overline{V_{i}^{n}}=$ weighted average of wage variances of the c groups, and $\operatorname{var}\left(\overline{X_{i}^{n}}\right)=$ variance of wage averages of the $\mathrm{c}$ groups.
} 
will pull the overall wage variance, $\mathrm{V}(\mathrm{c})$, below the variance prevailing without unions, $\mathrm{V}^{\mathrm{n}}(\mathrm{c})$. A positive covariance term indicates the opposite.

Over time, as Figures $1 b$ and $2 b$ have made clear, union power in the cases of both men and women has been shifting towards more skilled workers (the covariance term in equation (6) is becoming less negative). This factor will have offset the equalising tendency of unions brought about, in particular, by the variance gap. We now consider the size of these effects.

\section{Findings}

\section{The Economy As a Whole}

Table 1 contains panels for 1983 and 1995 that show how the overall variance in $\log$ wages has increased over the period. For men the increase has been $86 \log$ points (from 0.223 to 0.309 ), and for women it has been $64 \log$ points (from 0.192 to 0.256 ). These large increases are what we are concerned to explain. Notice that the increase in wage variance for non-union workers has been smaller: 66 points for men $(0.289$ to $0.355)$, and 40 points for women $(0.197$ to 0.237$)$. Thus, forces operating on the nonunion sector alone cannot explain the increase in overall wage variance, suggesting a role for deunionisation. The table also shows that the union wage variance is lower than the non-union, thereby pointing to the equalising effect of greater unionisation. ${ }^{7}$ Interestingly, it can also be seen that while both the union and non-union wage variances have risen over time, the union variance for men remains much smaller than the nonunion: the variance gap has increased. In other words, even though they are less extensive than heretofore, male unions can still strongly "standardise" their members' wages.

(Table 1 near here)

Table 1 also contains information on the wage gap, both unadjusted and adjusted for a set of conventional human capital variables. ${ }^{8}$ The unadjusted wage gaps are always

\footnotetext{
${ }^{7}$ Union wage variance remains much lower than the non-union variance when we standardise for differences in the characteristics of union and non-union workers. The variance of residuals from a wage regression for union workers is also lower than that for non-union workers.

${ }^{8}$ The adjusted union wage gap is the union coefficient from a regression controlling for years of education, years of experience (plus experience squared and cubed), and
} 
larger than the adjusted gaps because union workers have higher skills than their nonunion counterparts. However, the difference between adjusted and unadjusted wage gaps grows between 1983 and 1995, reflecting the increased unionisation of high skill groups in 1995. For men, the adjusted wage gap falls over time as well, reflecting reduced union power on this dimension (we must remember that male unions can still standardise members' wages). By contrast, female unions still seem to retain the power to bring about a wide wage gap (0.205 in 1995), but not so strongly to standardise their members' wages.

(Table 2 near here)

We now estimate basic union effects on wage dispersion, using equation (3). The results are given in Table 2. Taking males in 1983, for example, the 'within-sector' effect is $\mathrm{U} \Delta_{\mathrm{V}}=-0.078$, which is negative because the variance gap is negative. The 'between sector' effect is $\mathrm{U}(1-\mathrm{U}) \Delta_{\mathrm{W}}{ }^{2}=0.006$ which is positive, following the wage gap, but bound to be small since the wage gap term is squared. The total effect is -0.072 . This figure represents a sizeable contribution - about one-third - to reducing male wage variance in 1983 (0.223 from Table 1). In 1995, the impact is smaller, -0.053 , or about one-sixth of the male wage variance (0.309 from Table 1$)$. Taking changes over time, as in equation (4), male deunionisation contributes to a rise in wage variance of 0.019 , which is 21.1 per cent of the overall increase. As for women, we see that in 1983 unionism is weakly egalitarian, reducing wage variance by -0.012 . By 1995, however, women's unionism actually widens the wage variance by 0.003 . Over time, then, the impact of deunionisation for women is similar - namely, 23.4 per cent - but is achieved by a different route.

The last row of Table 2 shows the different estimates for deunionisation that are arrived at when we use the counterfactual of equation (5). It will be recalled that here we estimating what the 1995 wage variance would have been had the 1983 level of union density prevailed, taking as given the 1995 union wage and variance gaps. Using this method, deunionisation contributes 36.8 per cent to the widening in the male wage

dummies for non-white, marital status, and 5 regions. As will be seen, this two-sector wage gap does not play a major role in later calculations, and so we do not refine it. 
variance, but only 3.1 per cent in the case of females. However, as we have also noted, this method ignores changes in wage and variance gaps.

The next step is to allow for differences in union structure (i.e. in coverage and in wage and variance gaps) across skill groups, where the latter are defined using Card's (2001) predicted earnings deciles. We have already seen (from Figure 1b) how union power, for men, although once tending to be pro-poor, has become less so with the passage of time. And the trend is the same for women (Figure 2b). Table 3 now quantifies the impact of these trends.

(Table 3 near here)

The estimates in Table 3 serve to reduce the impact of deunionisation on wage dispersion for men, although not for women. Looking first at men, unions reduce overall wage variance in both years: by -0.43 in 1983 and by -0.41 in 1995 . However, as can be seen, the reduction is almost as great in 1995, which implies that deunionisation is only a small factor in the widening male wage variance. To put this finding another way: the counterfactual variance of wages if all were paid according to the non-union wage structure, $\mathrm{V}^{\mathrm{n}}(\mathrm{c})$, has increased by 0.084 , which is almost as much as the increase in the overall wage variance, 0.086 . Since the male non-union wage variance has increased so much, there is little room for a deunionisation effect.

The main factor behind the strong variance-reducing effect of unions for men in 1995 is the larger variance gap term: $\overline{U \Delta_{V}}=-0.033$ in 1995 compared with -0.026 in 1983 (see the lower panel of the table). In other words, unions standardise their members' pay more in 1995 than 1983. This factor counteracts the tendency for union power to become less pro-poor, as shown by the diminution of the covariance term (see also the flattening of the union power line in Figure 1b). On the other hand, the adjusted and simple estimates are similar for women. The dispersion-reducing effect of unions is estimated to be much larger in 1983 (at -0.015) than in $1995(-0.001)$. For women, union power has tended over time to become less egalitarian (see also Figure 2b). ${ }^{9}$

\footnotetext{
${ }^{9}$ We have the counterintuitive result for women that their average variance gap within skill groups, $\overline{\Delta_{\mathrm{v}}}$, is larger than the variance gap for the labour force as a whole, $\Delta_{\mathrm{v}}$. In 1995, for example, $\overline{\Delta_{\mathrm{V}}}=-0.07$, yet $\Delta_{\mathrm{V}}=-0.021$ (Table 2). The reason is that $\Delta_{\mathrm{V}}$ depends
} 
Consequently, the change in the character of women's unionisation appears to play a considerable role in the widening of women's wage variance.

These results differ from the received wisdom. In particular, it seems that the increase in wage dispersion for men can hardly be attributed to deunionisation. What unions have lost on the swings (less power among the unskilled) they have gained on the roundabouts (more wage compression for their members). It is true that deunionisation still seems to have a role to play in explaining increased wage dispersion among women. Nevertheless, we conclude that the equalising effects of unions are less than might be thought. Let us now consider whether distinguishing between the public and private sectors upsets this conclusion.

\section{Public-Private Sector Comparisons of Unionism}

It is interesting to assess the impact of deunionisation on wage inequality in the public and private sectors separately, since union trends have been so different. As can be seen from Tables $4 \mathrm{a}$ and 4b, public sector union density in 1995 is 78 to 85 per cent of its 1983 value. Indeed, some public sector groups such as women with further or higher education, have even maintained or increased in union density reflecting the rise in unionism among teachers and nurses. However, private sector density has declined considerably. In particular, the 1995 value for women (men) reaches only 55 (65) per cent of the 1983 value.

\section{(Tables $4 \mathrm{a}$ and $4 \mathrm{~b}$ near here)}

At the same time, the private and public sectors are similar in that the more educated categories have maintained their union density better than less educated groups. The picture is best appreciated from Figures 3 through 6, which graph the union power variable - union density multiplied by the wage gap - against predicted earnings (the covariance term in equation (6)). Men and women are shown separately by sector. The 1995 relationship is less negatively sloped than that for 1983 in all cases, and that for public sector women (Figure 6) turns distinctly positive.

(Figures 3 through 6 near here)

upon the distribution of union density across skill groups, as well as variance gaps within groups. The fact that most female union members are in the high skill groups, coupled with the fact that variance gaps are small for some of these groups drives $\Delta_{\mathrm{V}}$ down. 
We now calculate the basic union effects on wage dispersion. The necessary data are given in Tables 5a and 5b. Private-sector males are the group with the greatest wage variance in both years. In 1995, for example, overall wage variance for private sector males is 0.315 while the variance for all other groups ranges around 0.23 . Private-sector males have also had the greatest increase in wage variance over the years, namely, 0.083 (Table 6); for the other groups the increase has been around 0.06. However, only in the public sector has the increase in overall wage variance been much greater than the increase in the non-union group's wage variance. In the terminology of equation (4), the inequality $\mathrm{V}_{1}-\mathrm{V}_{0}>\mathrm{V}^{\mathrm{n}}{ }_{1}-\mathrm{V}^{\mathrm{n}}{ }_{0}$ holds strongly for the public sector. The implication is that deunionisation has influenced the wage distribution more in the public sector than in the private sector. Let us turn to the facts.

\section{(Tables $5 \mathrm{a}$ and $5 \mathrm{~b}$ near here)}

Basic estimates of the impact of deunionisation, following equation (3), are given in Table 6. This table is analogous to Table 2 for the whole economy. For example, for private-sector men in $1983,-0.063$ is an estimate of the amount by which unionisation reduces the wage variance. As can be seen, the impact of unions has fallen over time in both public and private sectors, just as for the economy as a whole. However, the fall has been greater in the public sector, implying a greater role for deunionisation. This is a surprising result given the fact that union density has fallen less in this sector. The second-last row gives the estimated contribution of deunionisation to the increased wage variance: 20.5 per cent for private-sector men, 4.8 per cent for private-sector women, 40.7 per cent for public-sector men, and 52.4 per cent for public-sector women. The final row shows, as a matter of interest, the very different estimate we would obtain using the counterfactual of equation (5).

(Table 6 near here)

We now turn to estimates that allow for different union effects by skill category. The results are given in Table 7, which is analogous to Table 3 for the whole economy. For men in both private and public sectors, as for the economy as a whole, the adjusted estimates are smaller than the basic estimates. This outcome is primarily because the variance gaps within skill categories are smaller than the variance gap for the sector. An indication of this fact is provided in the memo item in the last row of the table, which 
gives the average variance gap across skill categories, $\overline{\Delta_{\mathrm{v}}}$. For example, for privatesector men in 1983 this gap averages -0.05 , whereas for the private sector as a whole it is $-0.16(=0.132-0.292$, Table $5 a) .{ }^{10}$ Nevertheless, for men in both sectors the average variance gap has increased over time, as the memo item in the bottom panel indicates. On this measure, then, unions have increased their power in both sectors, even as union density has declined.

\section{(Table 7 near here)}

Pushing against this equalising effect has been the shift in union membership towards the labour elite, again in both sectors. The shift is given by the decline (in absolute value) in the covariance term given in the lower panel of Table 7 . The shift is also illustrated by the flatter union power graphs for 1995 (see Figures 3 and 5). For private-sector men, the net result is that unions reduce earnings variance by about the same amount (-0.031) in both 1983 and 1995. Therefore, deunionisation has apparently not contributed to the rise in male private sector wage variance. For men in the public sector, however, deunionisation still appears to make a contribution, accounting for nearly one-third of the increase in variance $(=0.016 / 0.059)$.

For women, the adjusted estimates make less difference. For private-sector women, deunionisation still has a very small effect, 0.003 ; one that is comparable to private-sector men. But for public-sector women, the deunionisation effect remains large, 0.028 , which is about $40 \%$ of the increase in variance. The large effect in this case does not result from a fall in union density, as might be thought, but rather from the shift towards elite workers in public-sector women's union density. In fact, for public-sector women in 1995, the usual negative, pro-poor covariance between skill and union power turned positive, 0.018 , as shown on the lower panel of Table 7 . In short, there has been a

\footnotetext{
${ }^{10}$ For public sector males in 1983 we have the extreme result that the average within skill group gap $\overline{\Delta_{\mathrm{V}}}=0$ (Table 7), while the overall gap $\Delta_{\mathrm{V}}=-0.09(=0.160-0.250$, Table $5 \mathrm{~b})$. This result arises because males in public sector unions in 1983 tended to be found in skill groups with high variance gaps, although variance gaps were zero averaged across skill groups (going the "wrong" way for several groups, with higher variance for union than non-union workers).
} 
change in the character of public-sector women's unionism, which the union density figures alone do not capture.

\section{Conclusions}

In this paper, we have analysed the impact of deunionisation on earnings dispersion over the period 1983-1995, taking men and women separately and also distinguishing between the private and public sectors. We have seen that unionism is a many-dimensioned entity. Union density is by no means the most important dimension. The variance and wage gaps attributable to unions are also important. So, too, is the "pro-poor" - or otherwise distribution of union density. In fact, we show (following Card, 2001) that the distribution of union density has become less pro-poor over time, shifting for example from the less educated to the better educated.

Our headline finding is that the large decline in union density accounts for little of the increase in earnings variation in the private sector, either for men or women. This finding can be explained by allowing for unionism's other dimensions. We show that the variance gap has widened sufficiently over time to offset both the decline in density and the adverse shift in density towards the more skilled. In the private sector, therefore, unions appear to have maintained their power - at least as regards standardising their members' wages - notwithstanding all Mrs Thatcher's reforms.

In the public sector there has been less of a decline in union density. Yet, paradoxically, it is here that unionism has had more of a role to play. In the public sector, as in the private sector, variance gaps - and thus the power to standardise - have been maintained. The difference lies in the shift towards organising the more skilled in the public sector, particularly amongst women. This means that unions no longer reduce earnings variation as much as they once did. Changes in the character of public sector unionism - not so much deunionisation as "re-unionisation" - can thus account for a large percentage (30 to $40 \%$ ) of the increased earnings dispersion in the public sector. But, to repeat, of the private sector no such statement can be made. 
Figure 1a: Union Density by Skill, Males in 1983 and 1995

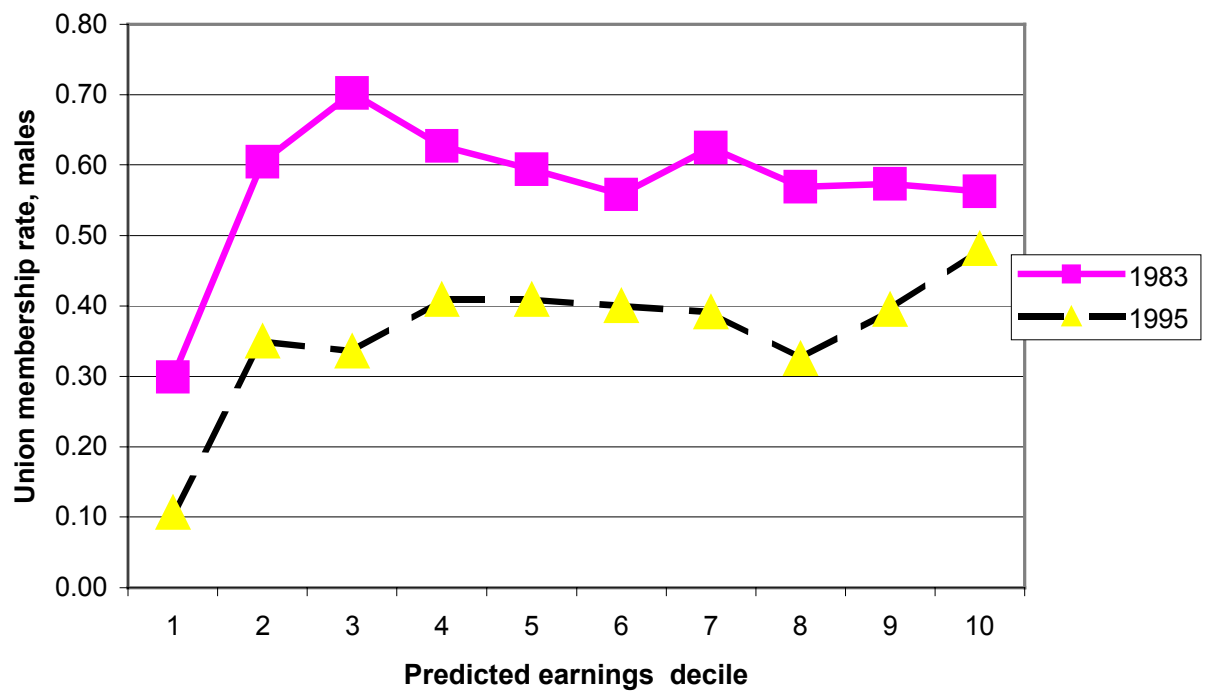

Figure 1b: "Union Power" by Skill, Males in 1983 and 1995

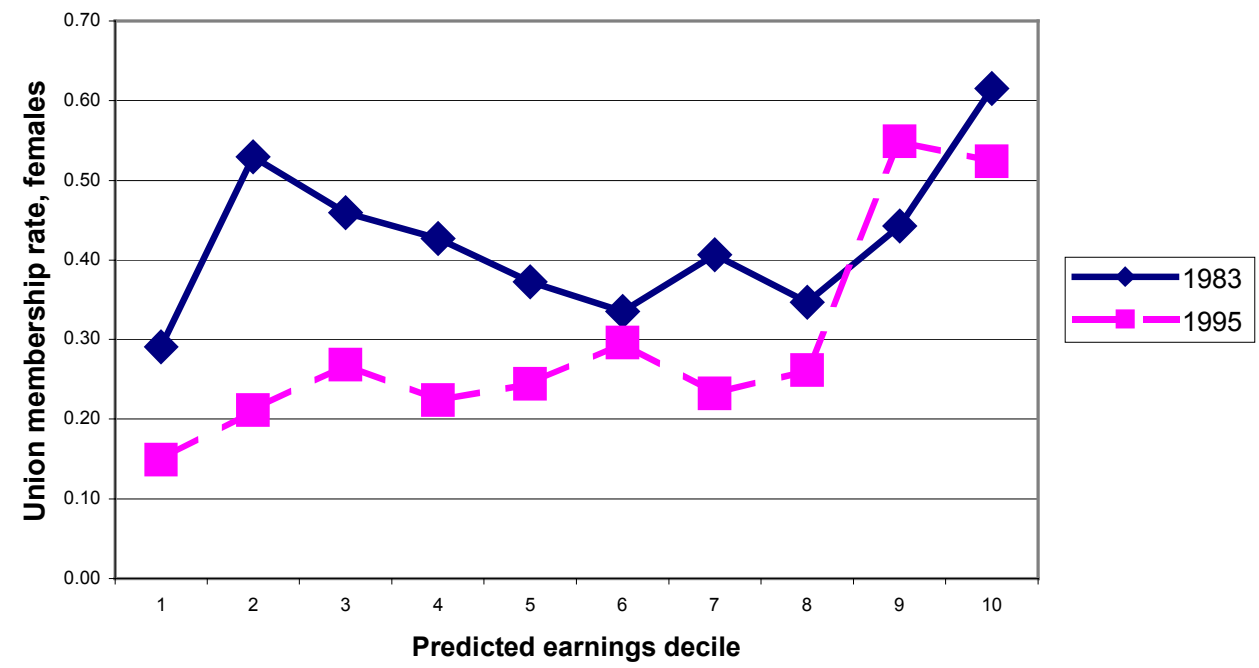


Figure 2a: Union Density by Skill, Females in 1983 and 1995

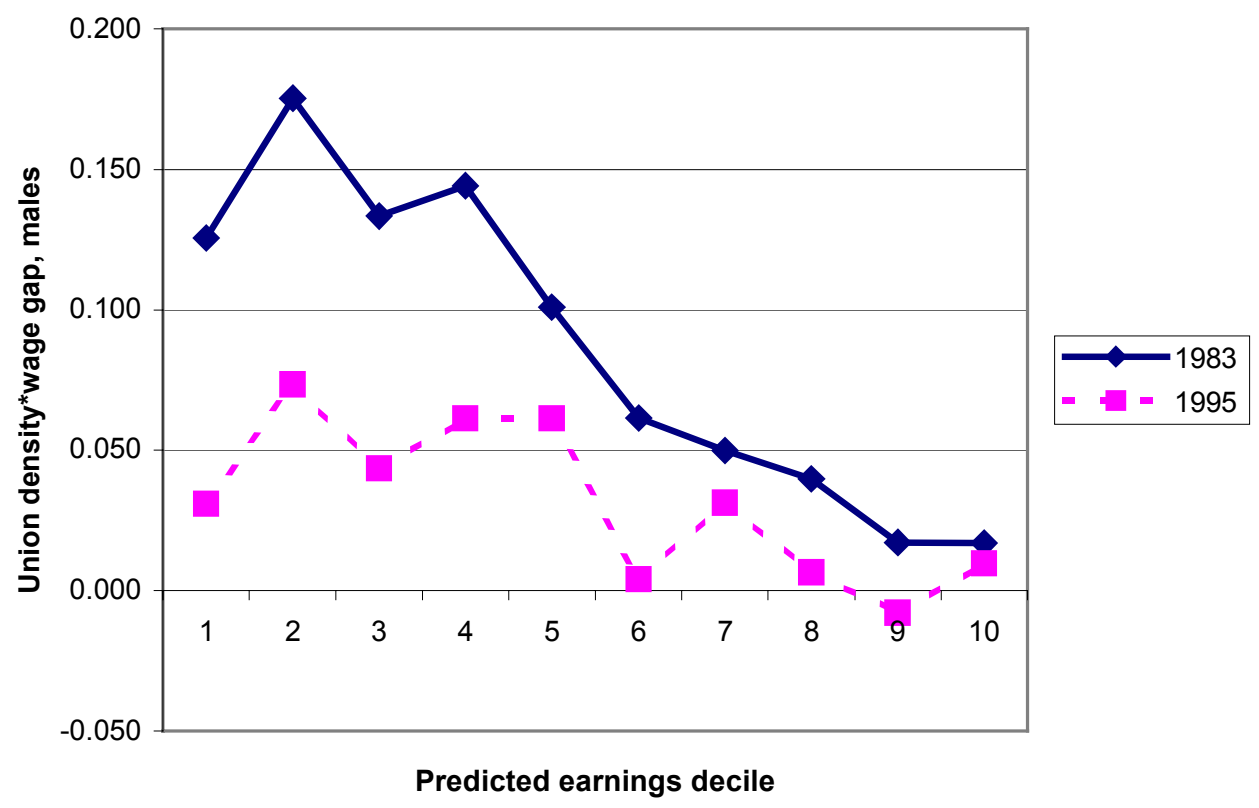

Figure 2b: "Union Power" by Skill, Females in 1983 and 1995

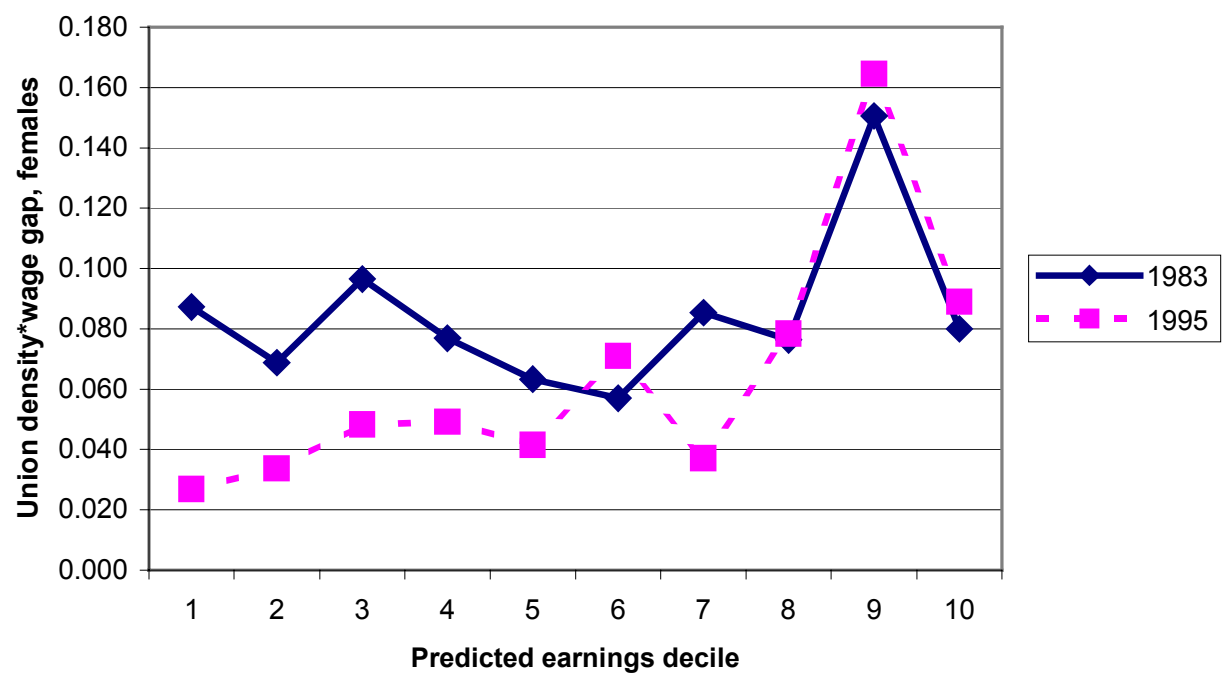


Figure 3: "Union Power" by Skill, Private-Sector Males in 1983 and 1995

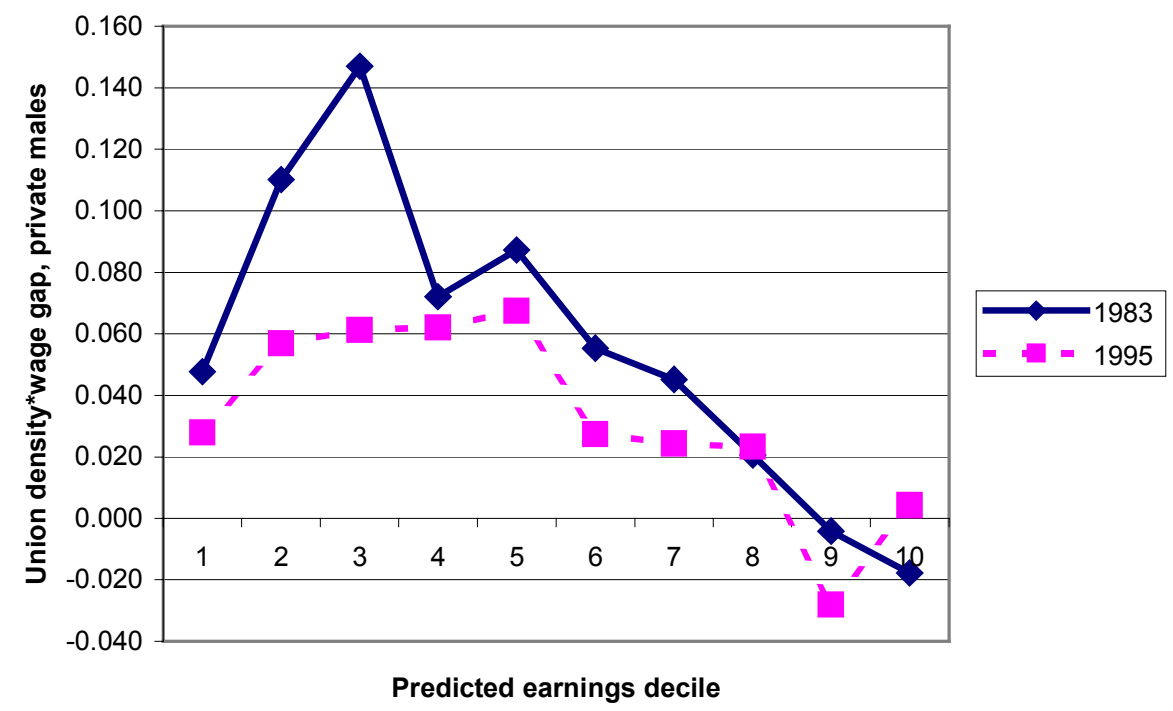

Figure 4: “Union Power” by Skill, Private-Sector Females in 1983 and 1995

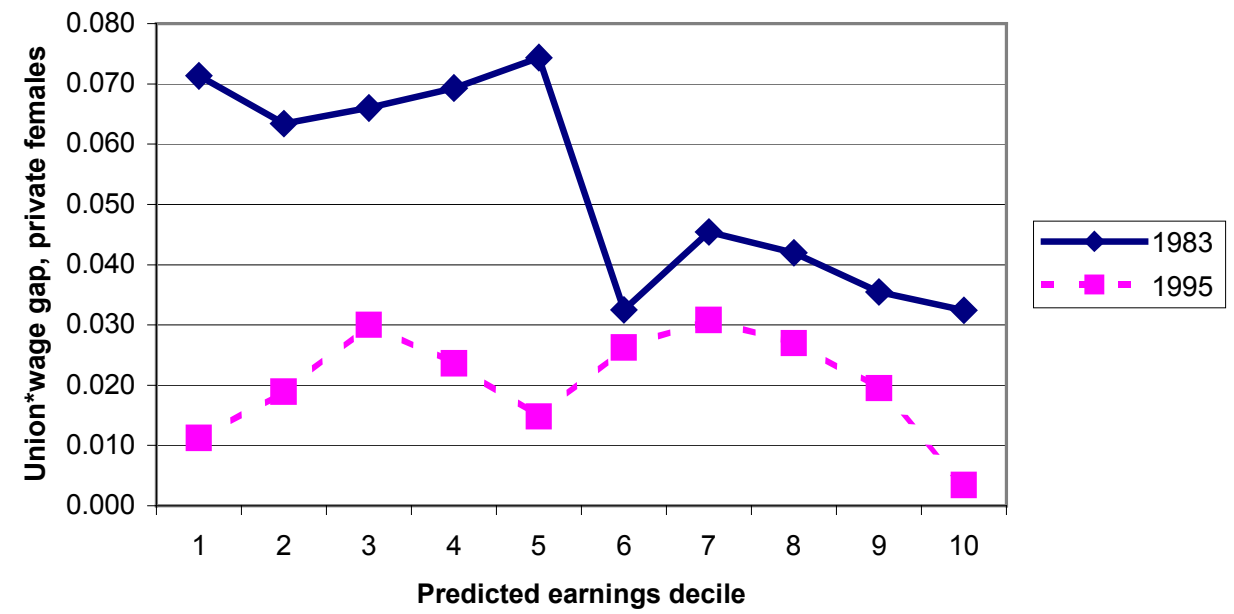


Figure 5: "Union Power" by Skill, Public-Sector Males in 1983 and 1995

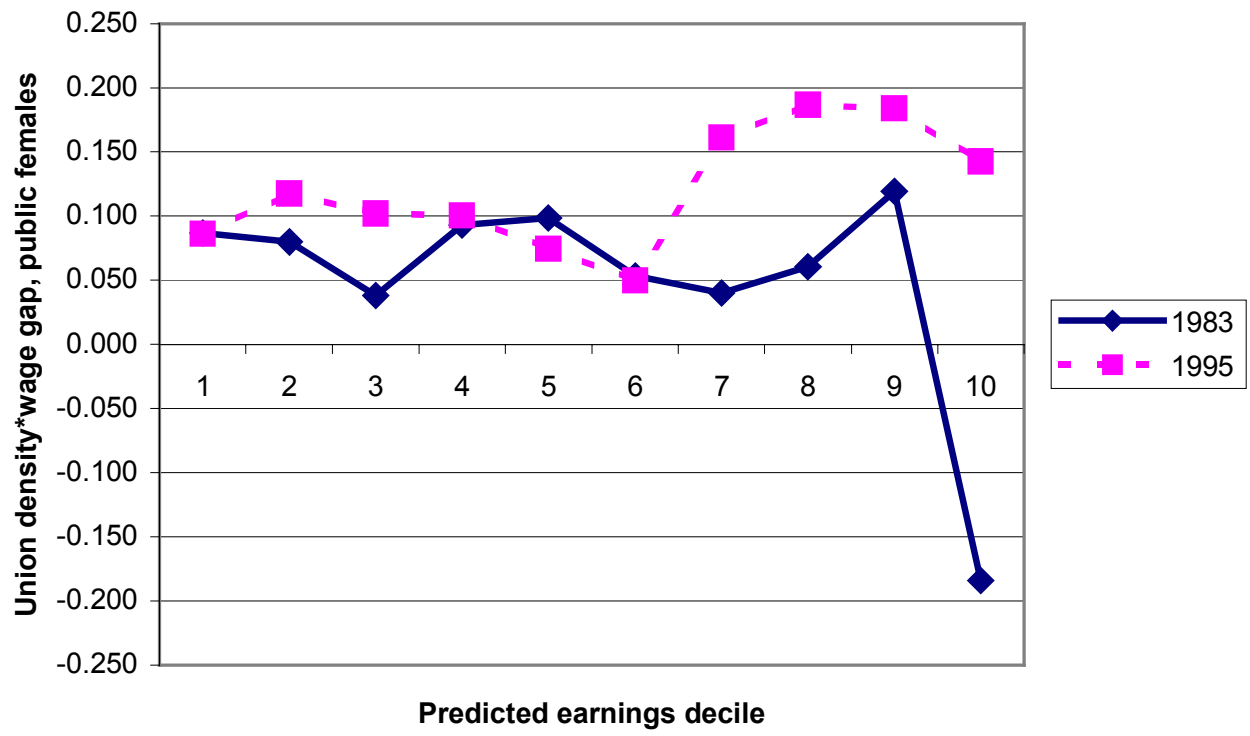

Figure 6: "Union Power” by Skill, Public-Sector Females in 1983 and 1995

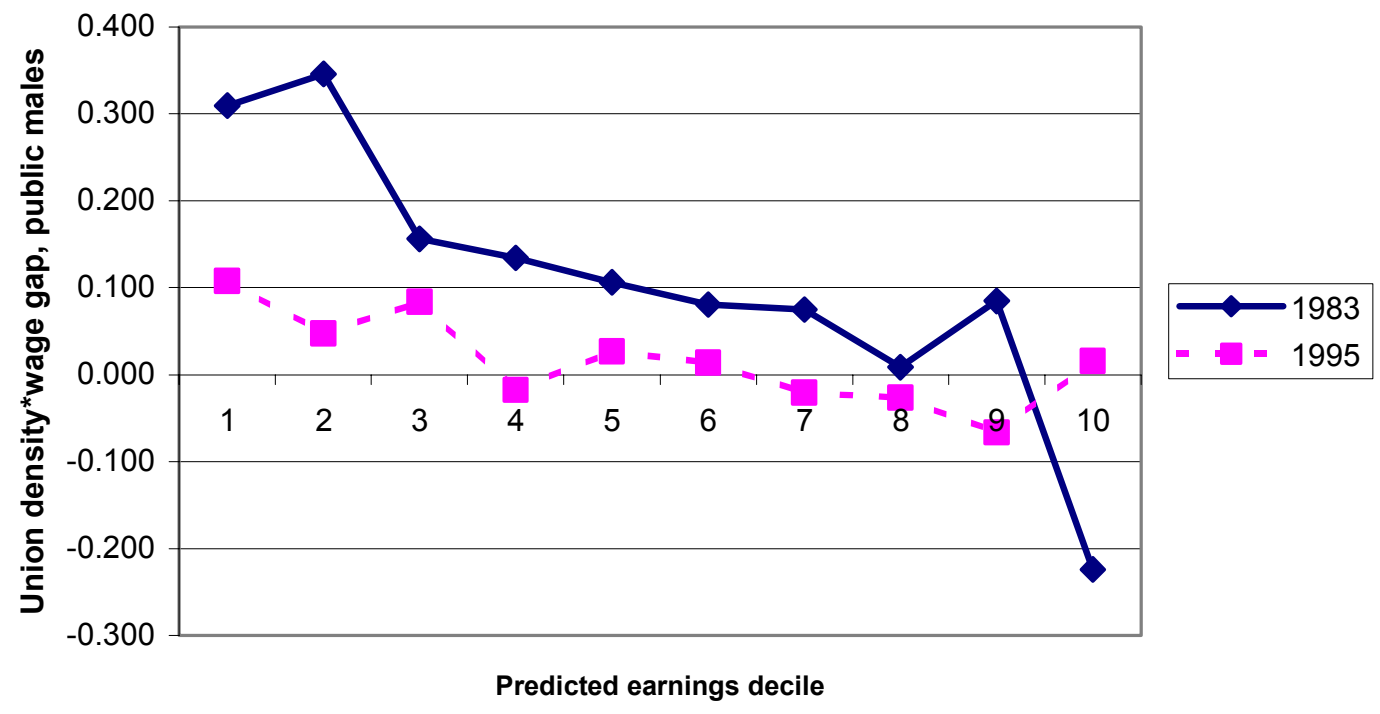


Table 1

Hourly Wage Distributions, Union and Non-Union Workers, 1983 and 1995

\begin{tabular}{|c|c|c|c|c|}
\hline & \multicolumn{2}{|c|}{ Men } & \multicolumn{2}{|l|}{ Women } \\
\hline & Non-union & Union & Non-union & Union \\
\hline \multicolumn{5}{|l|}{1983} \\
\hline Union density (\%) & \multicolumn{2}{|c|}{56.7} & \multicolumn{2}{|c|}{42.1} \\
\hline Overall variance log wages & \multicolumn{2}{|c|}{0.223} & \multicolumn{2}{|c|}{0.192} \\
\hline Variance log wage & 0.289 & 0.151 & 0.197 & 0.147 \\
\hline Mean log wage & 1.637 & 1.854 & 1.278 & 1.534 \\
\hline Adjusted union wage gap & \multicolumn{2}{|c|}{0.151} & \multicolumn{2}{|c|}{0.197} \\
\hline \multicolumn{5}{|l|}{1995} \\
\hline Union density (\%) & \multicolumn{2}{|c|}{36.0} & \multicolumn{2}{|c|}{29.8} \\
\hline Overall variance log wages & \multicolumn{2}{|c|}{0.309} & \multicolumn{2}{|c|}{0.256} \\
\hline Variance log wage & 0.355 & 0.202 & 0.237 & 0.216 \\
\hline Mean log wage & 1.860 & 2.05 & 1.54 & 1.89 \\
\hline Adjusted union wage gap & \multicolumn{2}{|c|}{0.086} & \multicolumn{2}{|c|}{0.205} \\
\hline
\end{tabular}

Notes: Samples are taken from the 1983 General Household Survey and the 1995 third quarter Labour Force Survey (LFS) with Northern Ireland excluded. Samples include respondents aged 16-66 years, who were not self-employed and whose hourly wage was between $£ 1$ and $£ 45$ in 1995 pounds (1983 wages valued in 1995 pounds according to the retail price index). For the LFS, income weights are used, as supplied with the data. The adjusted union wage gap is the union coefficient from a regression controlling for years of education, years of experience (plus experience squared and cubed), and dummies for non-white, marital status, and 5 regions. 
Table 2

Basic Estimates of the Contribution of Declining Unionisation to Wage Inequality, 1983-95

\begin{tabular}{|c|c|c|c|}
\hline & Men & Women & Remarks \\
\hline \multicolumn{4}{|l|}{1983} \\
\hline Union density, $\mathrm{U}$ & 0.567 & 0.421 & From Table 1. \\
\hline Union wage gap, $\Delta \mathrm{W}$ & 0.151 & 0.197 & $\begin{array}{l}\text { Adjusted difference between union and non-union } \\
\text { wages (Table 1). }\end{array}$ \\
\hline Union variance gap, $\Delta \mathrm{V}$ & -0.138 & -0.050 & $\begin{array}{l}\text { Difference in union and non-union wage variances } \\
\text { (Table 1). }\end{array}$ \\
\hline $\begin{array}{l}\text { Union effect, between } \\
\text { sectors, } \mathrm{U}(1-\mathrm{U}) \Delta \mathrm{W}^{2}\end{array}$ & 0.006 & 0.009 & $\begin{array}{l}\text { Small effect of unions in raising wage inequality by } \\
\text { widening mean pay as between union and non-union } \\
\text { sectors. }\end{array}$ \\
\hline \multirow{2}{*}{$\begin{array}{l}\text { Union effect, within } \\
\text { sectors, U } \Delta \mathrm{V} \\
\text { Total effect }\end{array}$} & -0.078 & -0.021 & $\begin{array}{l}\text { Larger effect of unions is to reduce wage dispersion } \\
\text { within union sectors. }\end{array}$ \\
\hline & -0.072 & -0.012 & $\begin{array}{l}\text { Estimated total effect of unions is to reduce wage } \\
\text { variance; for example, for men the reduction is -.072. }\end{array}$ \\
\hline \multicolumn{4}{|l|}{1995} \\
\hline \multirow{3}{*}{$\begin{array}{l}\text { Union density, } \mathrm{U} \\
\text { Union wage gap, } \Delta \mathrm{W} \\
\text { Union variance gap, } \Delta \mathrm{V}\end{array}$} & 0.360 & 0.298 & \multirow{3}{*}{ From Table 1.} \\
\hline & 0.086 & 0.205 & \\
\hline & -0.153 & -0.021 & \\
\hline $\begin{array}{l}\text { Union effect, between } \\
\text { sectors, } U(1-\mathrm{U}) \Delta \mathrm{W}^{2}\end{array}$ & 0.002 & 0.009 & \multirow[t]{2}{*}{ See explanations for 1983 above. } \\
\hline $\begin{array}{l}\text { Union effect, within } \\
\text { sectors, } \mathrm{U} \Delta \mathrm{V}\end{array}$ & -0.055 & -0.006 & \\
\hline Total effect & -0.053 & 0.003 & $\begin{array}{l}\text { Variance-reducing effect of unions is smaller for men } \\
\text { in } 1995 \text { than 1983, and unions even increase dispersion } \\
\text { for women in 1995. }\end{array}$ \\
\hline \multicolumn{4}{|l|}{ Changes: 1983-95 } \\
\hline $\begin{array}{l}\text { Change in variance of } \\
\text { wages }\end{array}$ & 0.086 & 0.064 & See Table 1; for example, for men $.086=.309-.223$. \\
\hline $\begin{array}{l}\text { Change in effect of } \\
\text { unions }\end{array}$ & 0.019 & 0.015 & $\begin{array}{l}\text { Change in total effect derived above; for example, for } \\
\text { men } .019=-.053-(-.072) \text {. }\end{array}$ \\
\hline $\begin{array}{l}\text { Contribution of unions } \\
(\%)\end{array}$ & 21.1 & 23.4 & For example, for men $.211=.019 / .086$. \\
\hline \multicolumn{4}{|l|}{ Memo item } \\
\hline $\begin{array}{l}\text { Amount } 1995 \mathrm{~V} \text { would } \\
\text { be lowered given } 1983 \mathrm{U} \\
(\%)^{*}\end{array}$ & $\begin{array}{l}0.032 \\
(36.8)\end{array}$ & $\begin{array}{l}0.002 \\
(3.1)\end{array}$ & $\begin{array}{l}\text { This number depends mainly on }\left(\mathrm{U}_{1}-\mathrm{U}_{0}\right) \Delta_{\mathrm{v} 1} \text {, the } \\
\text { change in } \mathrm{U} \text { weighted by the } 1995 \text { variance gap. This } \\
\text { gap is small for women; hence the } 3.1 \% \text { figure. }\end{array}$ \\
\hline
\end{tabular}

Note: * This number gives the deunionisation effect assuming changes only in union density; see text. 
Table 3

Adjusted Estimates of the Contribution of Declining Unionisation to Wage Inequality, Allowing for Different Union Effects Across Pay Deciles

\begin{tabular}{|c|c|c|c|}
\hline & Men & Women & Remarks \\
\hline \multicolumn{4}{|l|}{1983} \\
\hline Variance of wages & .223 & .192 & From Table 1. \\
\hline $\begin{array}{l}\text { Adjusted variance of non- } \\
\text { union wages, } V^{\mathrm{n}}(\mathrm{c})\end{array}$ & .266 & .207 & $\begin{array}{l}\text { Allowing for different union } \\
\text { impacts across pay deciles (see }\end{array}$ \\
\hline Adjusted union effect & -.043 & -.015 & Notes below). \\
\hline \multicolumn{4}{|l|}{1995} \\
\hline Variance in wages & .309 & .256 & From Table 1. \\
\hline $\begin{array}{l}\text { Adjusted variance in non- } \\
\text { union wages, } V^{\mathrm{n}}(\mathrm{c})\end{array}$ & .350 & .257 & $\begin{array}{l}\text { Allowing for different union } \\
\text { impacts across pay deciles (see }\end{array}$ \\
\hline Adjusted union effect & -.041 & -.001 & Notes below). \\
\hline \multicolumn{4}{|l|}{ Changes: 1983-95 } \\
\hline in variance of wages & .086 & .064 & \\
\hline $\begin{array}{l}\text { in adjusted variance of } \\
\text { non-union wages }\end{array}$ & .084 & .050 & \\
\hline in adjusted union effect & .002 & .014 & $\begin{array}{l}\text { For men, unions still have } \\
\text { considerable dispersion-reducing } \\
\text { effect in 1995. Hence the decline of } \\
\text { unions has hardly increased } \\
\text { dispersion. }\end{array}$ \\
\hline
\end{tabular}

Notes: The adjusted formula, allowing for different union effects on wage variance by skill category, is given in equation (6) in the text. Values for the terms in the equation (taken from the $\mathrm{c}=10$ decile groups in the Appendix) are as follows:

\begin{tabular}{lcccc}
\hline & \multicolumn{3}{c}{ Men } & \multicolumn{2}{c}{ Women } \\
\hline$\overline{U \Delta_{V}}$ & 1983 & 1995 & 1983 & 1995 \\
$\overline{U(1-U) \Delta_{w}^{2}}$ & -.026 & -.033 & -.030 & -.026 \\
$\operatorname{Var}\left[\mathrm{U}(\mathrm{c}) \Delta_{\mathrm{w}}(\mathrm{c})\right]$ & .009 & .004 & .011 & .009 \\
$2 \operatorname{Cov}\left[\mathrm{w}^{\mathrm{n}}(\mathrm{c}), \mathrm{U}(\mathrm{c}) \Delta_{\mathrm{w}}(\mathrm{c})\right]$ & .004 & .001 & .001 & .002 \\
$\operatorname{Total}$ & -.029 & -.013 & .003 & .014 \\
\hline Memo: $\overline{\Delta_{\mathrm{V}}}$ & -.043 & -.041 & -.015 & -.001 \\
\hline
\end{tabular}


Table 4a

Trade Union Membership Rates in the Private Sector, 1983 and 1995

\begin{tabular}{|c|c|c|c|c|c|c|}
\hline & \multicolumn{3}{|c|}{ Men } & \multicolumn{3}{|c|}{ Women } \\
\hline & 1983 & 1995 & $\begin{array}{l}\text { Ratio } \\
95 / 83\end{array}$ & 1983 & 1995 & $\begin{array}{l}\text { Ratio } \\
95 / 83\end{array}$ \\
\hline Overall & 41.9 & 27.3 & 65.2 & 26.0 & 14.7 & 55.0 \\
\hline By education: & & & & & & \\
\hline $\begin{array}{l}\text { Degree or } \\
\text { equivalent }\end{array}$ & 13.4 & 18.4 & 94.8 & 30.2 & 14.2 & 47.0 \\
\hline $\begin{array}{l}\text { Further } \\
\text { education }\end{array}$ & 40.6 & 24.3 & 59.9 & 27.3 & 21.8 & 79.8 \\
\hline $\begin{array}{l}\text { 'A' level or } \\
\text { equivalent }\end{array}$ & 39.3 & 32.2 & 81.9 & 20.2 & 17.7 & 87.6 \\
\hline $\begin{array}{l}\text { 'O' level or } \\
\text { equivalent }\end{array}$ & 30.0 & 17.2 & 57.3 & 21.4 & 14.4 & 67.3 \\
\hline Other & 47.8 & 38.3 & 80.1 & 21.4 & 11.8 & 55.1 \\
\hline None & 49.8 & 25.5 & 51.2 & 30.9 & 13.4 & 43.4 \\
\hline Observations & 2,883 & 3,140 & & 2,186 & 2,728 & \\
\hline
\end{tabular}

Sources: Samples are taken from the 1983 General Household Survey, and the third quarter 1995 Labour Force Survey. The public sector is defined to include nationalised industries, public corporations, and central and local government.

Table 4b

Trade Union Membership Rates in the Public Sector, 1983 and 1995

\begin{tabular}{lcccccc}
\hline & \multicolumn{3}{c}{ Men } & \multicolumn{3}{r}{ Women } \\
\cline { 2 - 7 } & 1983 & 1995 & $\begin{array}{l}\text { Ratio } \\
95 / 83\end{array}$ & 1983 & 1995 & $\begin{array}{l}\text { Ratio } \\
95 / 83\end{array}$ \\
\hline $\begin{array}{l}\text { Overall } \\
\text { By education: }\end{array}$ & 84.9 & 66.0 & 77.7 & 68.7 & 58.3 & 84.9 \\
$\begin{array}{l}\text { Degree or } \\
\text { equivalent }\end{array}$ & 81.2 & 71.9 & 88.5 & 76.1 & 73.3 & 96.3 \\
$\quad \begin{array}{l}\text { Further } \\
\text { education }\end{array}$ & 85.2 & 78.1 & 91.7 & 73.9 & 79.0 & 1.07 \\
$\begin{array}{c}\text { 'A' level or } \\
\text { equivalent } \\
\text { 'O' level or }\end{array}$ & 83.6 & 56.2 & 67.2 & 68.2 & 45.2 & 66.3 \\
$\begin{array}{c}\text { equivalent } \\
\quad \text { Other }\end{array}$ & 79.5 & 60.8 & 76.5 & 64.3 & 46.8 & 72.8 \\
$\quad$ None & 85.5 & 55.4 & 64.8 & 65.0 & 49.0 & 75.4 \\
\hline Observations & 1,557 & 923 & & 67.9 & 46.5 & 68.5 \\
\hline
\end{tabular}

Sources: See Table 4a. 
Table 5a

Hourly Wage Distributions in the Private Sector, 1983 and 1995

\begin{tabular}{|c|c|c|c|c|}
\hline & \multicolumn{2}{|c|}{ Men } & \multicolumn{2}{|c|}{ Women } \\
\hline & Non-union & Union & Non-union & Union \\
\hline \multicolumn{5}{|l|}{1983} \\
\hline Union density $(\%)$ & \multicolumn{2}{|c|}{41.9} & \multicolumn{2}{|c|}{26.0} \\
\hline Overall variance log wages & \multicolumn{2}{|c|}{0.232} & \multicolumn{2}{|c|}{0.168} \\
\hline Variance log wage by group & 0.292 & 0.132 & 0.180 & 0.111 \\
\hline Mean log hourly wage & 1.62 & 1.78 & 1.22 & 1.41 \\
\hline Adjusted union wage gap & \multicolumn{2}{|c|}{0.132} & \multicolumn{2}{|c|}{0.206} \\
\hline \multicolumn{5}{|l|}{1995} \\
\hline Union density $(\%)$ & \multicolumn{2}{|c|}{27.3} & \multicolumn{2}{|c|}{15.1} \\
\hline Overall variance log wages & \multicolumn{2}{|c|}{0.315} & \multicolumn{2}{|c|}{0.231} \\
\hline Variance log wage by group & 0.358 & 0.185 & 0.237 & 0.179 \\
\hline Mean log hourly wage & 1.84 & 1.98 & 1.51 & 1.68 \\
\hline Adjusted union wage gap & \multicolumn{2}{|c|}{0.097} & \multicolumn{2}{|c|}{0.130} \\
\hline
\end{tabular}

Notes: See Table 2

Table 5b

Hourly Wage Distributions in the Public Sector, 1983 and 1995

\begin{tabular}{llccc}
\hline & \multicolumn{2}{c}{ Men } & \multicolumn{2}{c}{ Women } \\
\cline { 2 - 5 } & Non-union & Union & Non-union & Union \\
\hline $\mathbf{1 9 8 3}$ & \multicolumn{2}{c}{84.9} & & 68.7 \\
Union density (\%) & \multicolumn{2}{c}{0.176} & 0.171 \\
Overall variance log wages & 0.250 & 0.160 & 0.200 & 0.152 \\
Variance log wage by group & 0.250 & 1.49 & 1.61 \\
Mean log hourly wage & 1.77 & 1.91 & & 0.099 \\
Adjusted union wage gap & & 0.115 & & 58.3 \\
\hline $\mathbf{1 9 9 5}$ & & 65.9 & & 0.234 \\
Union density (\%) & & 0.235 & 0.217 & 0.202 \\
Overall variance log wages & & 0.207 & 0.217 & 2.00 \\
Variance log wage, by group & 0.283 & 2.16 & 1.67 & 0.208 \\
Mean log hourly wage & 2.07 & 0.040 & & \\
Adjusted union wage gap & & &
\end{tabular}

Notes: See Table 2. 
Table 6

Basic Estimates of the Contribution of Declining Unionisation to Wage Inequality in the Private and Public Sectors, 1983-95

\begin{tabular}{|c|c|c|c|c|}
\hline & \multicolumn{2}{|c|}{ Private sector } & \multicolumn{2}{|c|}{ Public sector } \\
\hline & Men & Women & Men & Women \\
\hline \multicolumn{5}{|l|}{1983} \\
\hline $\begin{array}{l}\text { Union effect, } \\
\text { between sectors, } \\
\mathrm{U}(1-\mathrm{U}) \Delta \mathrm{W}^{2}\end{array}$ & 0.004 & 0.008 & 0.002 & 0.002 \\
\hline $\begin{array}{l}\text { Union effect, within } \\
\text { sectors, } U \Delta V\end{array}$ & -0.067 & -0.018 & -0.076 & -0.033 \\
\hline Total effect & -0.063 & -0.010 & -0.074 & -0.031 \\
\hline \multicolumn{5}{|l|}{1995} \\
\hline $\begin{array}{l}\text { Union effect, } \\
\text { between sectors, } \\
\mathrm{U}(1-\mathrm{U}) \Delta \mathrm{W}^{2}\end{array}$ & 0.002 & 0.002 & 0.0 & 0.011 \\
\hline $\begin{array}{l}\text { Union effect, within } \\
\text { sectors, } U \Delta \mathrm{V}\end{array}$ & -0.048 & -0.009 & -0.05 & -0.009 \\
\hline Total effect & -0.046 & -0.007 & -0.05 & 0.002 \\
\hline \multicolumn{5}{|l|}{ Changes: $1983-95$} \\
\hline $\begin{array}{l}\text { Change in variance } \\
\text { of wages }\end{array}$ & 0.083 & 0.063 & 0.059 & 0.063 \\
\hline $\begin{array}{l}\text { Change in effect of } \\
\text { unions }\end{array}$ & 0.017 & 0.003 & 0.024 & 0.033 \\
\hline $\begin{array}{l}\text { Contribution of } \\
\text { unions (\%) }\end{array}$ & 20.5 & 4.8 & 40.7 & 52.4 \\
\hline \multicolumn{5}{|l|}{ Memo item } \\
\hline $\begin{array}{l}\text { Amount } 1995 \mathrm{~V} \\
\text { would be lowered } \\
\text { given } 1983 \mathrm{U}(\%)\end{array}$ & $\begin{array}{l}0.025 \\
(30.1)\end{array}$ & $\begin{array}{l}0.005 \\
(7.9)\end{array}$ & $\begin{array}{l}0.014 \\
(23.7)\end{array}$ & $\begin{array}{l}0.003 \\
(4.8)\end{array}$ \\
\hline
\end{tabular}

Notes: See Table 2. 
Table 7

Adjusted Estimates of the Contribution of Declining Unionisation to Wage Inequality, Allowing for Different Union Effects Across Pay Deciles

\begin{tabular}{|c|c|c|c|c|}
\hline & \multicolumn{2}{|c|}{ Private sector } & \multicolumn{2}{|c|}{ Public sector } \\
\hline & Men & Women & Men & Women \\
\hline 1983 & & & & \\
\hline Variance in wages & .232 & .168 & .176 & .171 \\
\hline $\begin{array}{l}\text { Adjusted variance of } \\
\text { non-union wages, } \mathrm{V}^{\mathrm{n}}(\mathrm{c})\end{array}$ & .263 & .175 & .242 & .217 \\
\hline Adjusted union effect & -.031 & -.007 & -.065 & -.046 \\
\hline 1995 & & & & \\
\hline Variance in log wages & .315 & .231 & .235 & .234 \\
\hline $\begin{array}{l}\text { Adjusted variance of } \\
\text { non-union wages, } V^{n}(c)\end{array}$ & .346 & .235 & .285 & .252 \\
\hline Adjusted union effect & -.031 & -.004 & -.050 & -.018 \\
\hline $\begin{array}{l}\text { Changes: } 1983-95 \\
\text { in variance of wages }\end{array}$ & .083 & .063 & .059 & .063 \\
\hline $\begin{array}{l}\text { in adjusted variance of } \\
\text { non-union wages }\end{array}$ & .083 & .060 & .043 & .035 \\
\hline in adjusted union effect & 0 & .003 & .016 & .028 \\
\hline
\end{tabular}

Notes: See Table 4. The adjusted formula (allowing for different union effects by skill category) for the effect of unions on the variance of wages is given in equation (6) in the text. Values for the terms in the equation are as follows:-

\begin{tabular}{lcccccccc}
\hline & \multicolumn{3}{c}{ Private sector } & \multicolumn{3}{c}{ Public sector } \\
& \multicolumn{2}{c}{ Men } & \multicolumn{2}{c}{ Women } & \multicolumn{2}{c}{ Men } & \multicolumn{2}{c}{ Women } \\
\hline$\overline{\mathrm{U} \Delta_{\mathrm{V}}}$ & 1983 & 1995 & 1983 & 1995 & 1983 & 1995 & 1983 & 1995 \\
$\overline{\mathrm{U}(1-U) \Delta_{w}^{2}}$ & -.020 & -.023 & -.011 & -.006 & .008 & -.023 & -.020 & -.044 \\
$\operatorname{Var}\left[\mathrm{U}(\mathrm{c}) \Delta_{\mathrm{w}}(\mathrm{c})\right]$ & .007 & .005 & .009 & .003 & .007 & .002 & .004 & .007 \\
$2 \operatorname{Cov}[\mathrm{w}(\mathrm{c})$, & -.003 & .001 & 0 & 0 & .025 & .004 & .007 & .002 \\
$\left.\mathrm{U}(\mathrm{c}) \Delta_{\mathrm{w}}(\mathrm{c})\right]$ & -.014 & -.005 & -.001 & -.106 & -.033 & -.037 & .017 \\
$\operatorname{Total}$ & -.031 & -.031 & -.007 & -.004 & -.066 & -.050 & -.046 & -.018 \\
\hline $\operatorname{Memo:} \overline{\Delta_{\mathrm{V}}}$ & -.05 & -.08 & -.04 & -.04 & 0 & -.04 & -.03 & -.08 \\
\hline
\end{tabular}




\section{Appendix Table \\ Union Membership Rates and Union Wage Effects by Pay Decile}

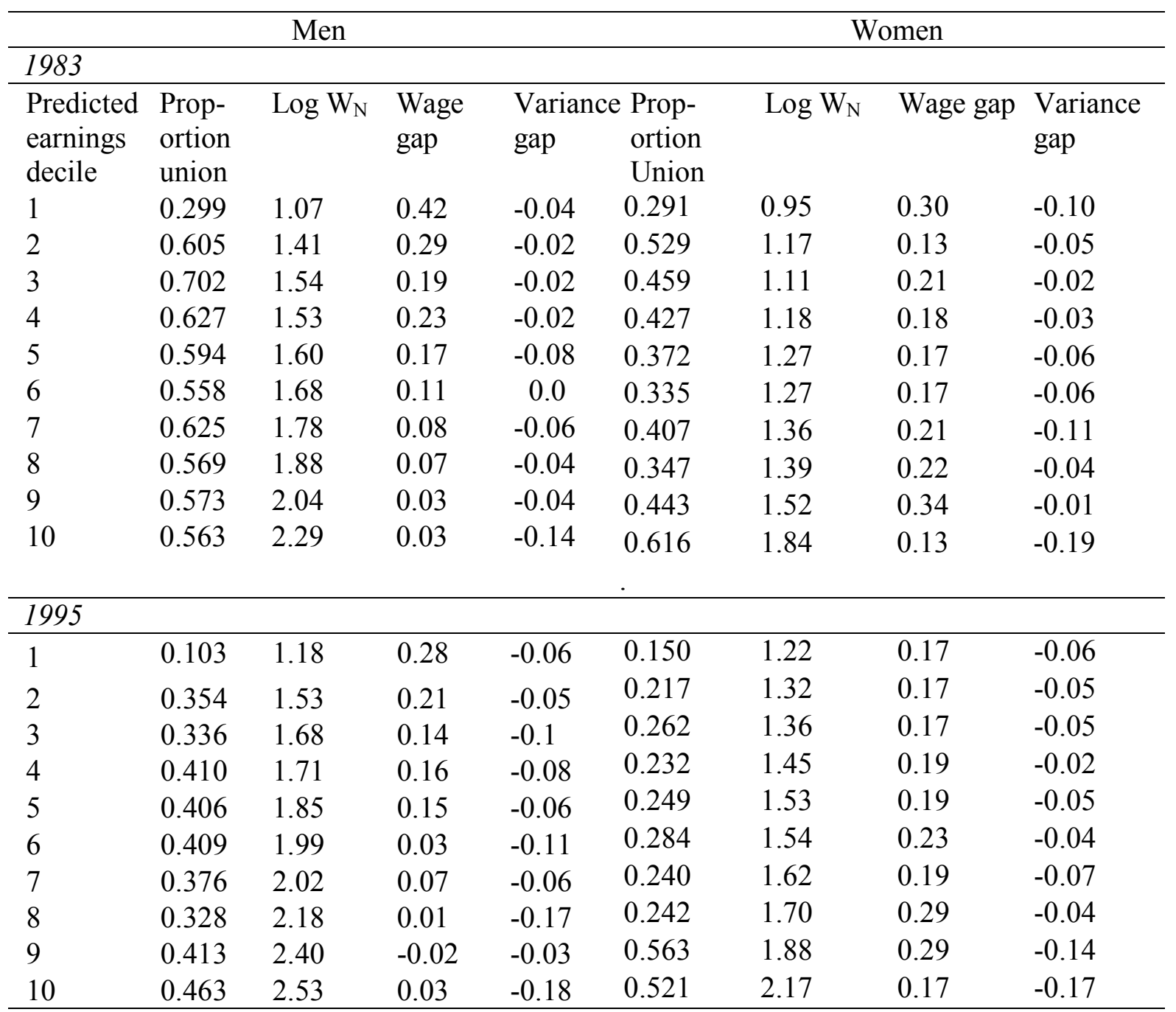

Notes: Predicted earnings decile is based on a prediction equation for the non-union sector, using an equation with years of education, experience, experience squared and cubed, dummies for marital status, non-white and 5 regions, and interaction of 5 levels of education with education and linear and quadratic experience. The wage gap is the difference between the log of hourly earnings between union and non-union workers for the given decile. The variance gap is the difference in the variance of log earnings between union and non-union workers for the given decile. 


\section{References}

Bell, Brian and Michael Pitt (1998), 'Trade Union Decline and Distribution of Wages in the UK: Evidence from Kernel Density Estimation', Oxford Bulletin of Economics and Statistics, 60 (4), November: 509-28.

Brook, Keith (2002), 'Trade Union Membership: An Analysis of Data from the Autumn 2001 LFS', Labour Market Trends, 110(7), July: 343-54.

Card, David (2001), 'The Effect of Unions on Wage Inequality in the U.S. Labor Market', Industrial and Labor Relations Review, 54 (2) January, 296-315.

Freeman, Richard (1980), 'Unionism and the Dispersion of Wages', Industrial and Labor Relations Review, 34 (1) October, 3-23.

Card, David, Thomas Lemieux, and W. Craig Riddell (2002), 'Unions and the Wage Structure', in John T. Addison and Claus Schnabel (eds.), International Handbook of Trade Unions. Cheltenham: Edward Elgar [forthcoming].

Freeman, Richard (1991), 'How Much Has De-Unionisation Contributed to the Rise in Male Wage Inequality?’ NBER Working Paper No. 3826. Cambridge, Mass.: National Bureau of Economic Research.

Gosling, Amanda and Thomas Lemieux (2001), 'Labor Market Reforms and Changes in Wage Inequality in the United Kingdom and the United States', NBER Working Paper No. 8413,. Cambridge, Mass.: National Bureau of Economic Research.

Gosling, Amanda, Stephen Machin, and Costas Meghir (2000), 'The Changing Distribution of Male Wages in the U.K.', Review of Economic Studies, 67 (4) 635-66.

Derek Leslie and Yonghao $\mathrm{Pu}$ (1996), 'What Caused Rising Earnings Inequality in Britain? Evidence from Time Series, 1970-1993', British Journal of Industrial Relations, 34 (1), March: 111-30.

Machin, Stephen (1997), 'The Decline of Labour Market Institutions and the Rise in Wage Inequality in Britain', European Economic Review, 41 (3-5) April, 647-57.

Schmitt, John (1995), 'The Changing Structure of Male Earnings in Britain, 1974-1988', in Richard B. Freeman and Lawrence F. Katz (eds.), Differences and Changes in Wage Structures, Chicago, Ill.: University of Chicago Press, pp. 177-204.

Metcalf, David (1982), 'Unions and the Distribution of Earnings', British Journal of Industrial Relations, 20 (2), July: 163-69. 
OPCS (1986), General Household Survey, 1983 [computer file]. London: Office of Population Censuses and Surveys Social Survey Division; Colchester, U.K.: The Data Archive [distributor], SN: 2099.

OPCS (2000), Quarterly Labour Force Survey, September-November, 1995 [computer file], 3rd ed. London: Office of Population Censuses and Surveys Social Survey Division, Department of Finance and Personnel (Northern Ireland) Central Survey Unit; Colchester, U.K.: The Data Archive [distributor], SN: 3528. 


\section{IZA Discussion Papers}

\begin{tabular}{|c|c|c|c|c|}
\hline No. & Author(s) & Title & Area & Date \\
\hline 709 & $\begin{array}{l}\text { L. Danziger } \\
\text { S. Neuman }\end{array}$ & $\begin{array}{l}\text { Delays in Renewal of Labor Contracts: Theory } \\
\text { and Evidence }\end{array}$ & 1 & $02 / 03$ \\
\hline 710 & $\begin{array}{l}\text { Z. Eckstein } \\
\text { Y. Weiss }\end{array}$ & $\begin{array}{l}\text { On the Wage Growth of Immigrants: Israel, } \\
1990-2000\end{array}$ & 2 & $02 / 03$ \\
\hline 711 & C. Ruhm & Healthy Living in Hard Times & 3 & $02 / 03$ \\
\hline 712 & $\begin{array}{l}\text { E. Fehr } \\
\text { J. Henrich }\end{array}$ & $\begin{array}{l}\text { Is Strong Reciprocity a Maladaptation? On the } \\
\text { Evolutionary Foundations of Human Altruism }\end{array}$ & 5 & $02 / 03$ \\
\hline 713 & $\begin{array}{l}\text { I. Gang } \\
\text { J. Landon-Lane } \\
\text { M. S. Yun }\end{array}$ & $\begin{array}{l}\text { Does the Glass Ceiling Exist? A Cross-National } \\
\text { Perspective on Gender Income Mobility }\end{array}$ & 2 & $02 / 03$ \\
\hline 714 & M. Fertig & $\begin{array}{l}\text { Educational Production, Endogenous Peer } \\
\text { Group Formation and Class Composition - } \\
\text { Evidence From the PISA } 2000 \text { Study }\end{array}$ & 6 & $02 / 03$ \\
\hline 715 & $\begin{array}{l}\text { E. Fehr } \\
\text { U. Fischbacher } \\
\text { B. von Rosenbladt } \\
\text { J. Schupp } \\
\text { G. G. Wagner }\end{array}$ & $\begin{array}{l}\text { A Nation-Wide Laboratory Examining Trust and } \\
\text { Trustworthiness by Integrating Behavioral } \\
\text { Experiments into Representative Surveys }\end{array}$ & 7 & $02 / 03$ \\
\hline 716 & $\begin{array}{l}\text { M. Rosholm } \\
\text { L. Skipper }\end{array}$ & $\begin{array}{l}\text { Is Labour Market Training a Curse for the } \\
\text { Unemployed? Evidence from a Social } \\
\text { Experiment }\end{array}$ & 6 & $02 / 03$ \\
\hline 717 & $\begin{array}{l}\text { A. Hijzen } \\
\text { H. Görg } \\
\text { R. C. Hine }\end{array}$ & $\begin{array}{l}\text { International Fragmentation and Relative Wages } \\
\text { in the UK }\end{array}$ & 2 & $02 / 03$ \\
\hline 718 & E. Schlicht & Consistency in Organization & 1 & $02 / 03$ \\
\hline 719 & $\begin{array}{l}\text { J. Albrecht } \\
\text { P. Gautier } \\
\text { S. Vroman }\end{array}$ & $\begin{array}{l}\text { Equilibrium Directed Search with Multiple } \\
\text { Applications }\end{array}$ & 3 & $02 / 03$ \\
\hline 720 & T. Palokangas & $\begin{array}{l}\text { Labour Market Regulation, Productivity- } \\
\text { Improving R\&D and Endogenous Growth }\end{array}$ & 3 & $02 / 03$ \\
\hline 721 & $\begin{array}{l}\text { H. Battu } \\
\text { M. Mwale } \\
\text { Y. Zenou }\end{array}$ & $\begin{array}{l}\text { Do Oppositional Identities Reduce Employment } \\
\text { for Ethnic Minorities? }\end{array}$ & 1 & $02 / 03$ \\
\hline 722 & $\begin{array}{l}\text { C. K. Spiess } \\
\text { F. Büchel } \\
\text { G. G. Wagner }\end{array}$ & $\begin{array}{l}\text { Children's School Placement in Germany: Does } \\
\text { Kindergarten Attendance Matter? }\end{array}$ & 6 & $02 / 03$ \\
\hline 723 & $\begin{array}{l}\text { M. Coles } \\
\text { B. Petrongolo }\end{array}$ & $\begin{array}{l}\text { A Test between Unemployment Theories Using } \\
\text { Matching Data }\end{array}$ & 3 & $02 / 03$ \\
\hline 724 & $\begin{array}{l}\text { J. T. Addison } \\
\text { R. Bailey } \\
\text { W. S. Siebert }\end{array}$ & $\begin{array}{l}\text { The Impact of Deunionisation on Earnings } \\
\text { Dispersion Revisited }\end{array}$ & 2 & $02 / 03$ \\
\hline
\end{tabular}

An updated list of IZA Discussion Papers is available on the center's homepage www.iza.org. 